\title{
Prevalence and Associated Factors of Tuberculosis in Prisons Settings of East Gojjam Zone, Northwest Ethiopia
}

\author{
Mucheye Gizachew Beza, ${ }^{1}$ Emirie Hunegnaw, ${ }^{2}$ and Moges Tiruneh ${ }^{1}$ \\ ${ }^{1}$ Department of Medical Microbiology, School of Biomedical and Laboratory Sciences, College of Medicine and Health Sciences, \\ University of Gondar, P.O. Box 196, Gondar, Ethiopia \\ ${ }^{2}$ Laboratory Section, Motta Hospital, Motta, Ethiopia
}

Correspondence should be addressed to Mucheye Gizachew Beza; muchegiza@gmail.com

Received 20 May 2017; Revised 4 August 2017; Accepted 13 September 2017; Published 17 October 2017

Academic Editor: Doris Hillemann

Copyright (C) 2017 Mucheye Gizachew Beza et al. This is an open access article distributed under the Creative Commons Attribution License, which permits unrestricted use, distribution, and reproduction in any medium, provided the original work is properly cited.

\begin{abstract}
Background. Tuberculosis, mainly in prisoners, is a major public health problem in Ethiopia where there is no medical screening during prison admission. This creates scarcity of TB data in such settings. Objective. To determine prevalence and associated factors of TB in prisons in East Gojjam Zone, Northwest Ethiopia. Methods. A cross-sectional study was conducted from February to May 2016 among 265 prisoners in three prison sites. Sputum was processed using GeneXpert MTB/RIF. Data were analyzed using SPSS version 20.0. Multivariable logistic regression was used; $p$ values $=0.05$ were considered statistically significant. Results. Of 265 prisoners, $9(3.4 \%)$ were TB positive (males); $77.8 \%, 55.6 \%$, and $55.6 \%$ of cases were rural dwellers, married, and farmers, respectively. Seven (2.6\%) prisoners were HIV positive, and $3(1.13 \%)$ had TB/HIV coinfection. One (0.4\%) TB case was rifampicin resistant. Marriage $(\mathrm{AOR}=1.5 ; 95 \% \mathrm{CI}: 1.7,13.03), \mathrm{HIV}(\mathrm{AOR}=0.14 ; 95 \% \mathrm{CI}: 0.001,0.17)$, and sharing of rooms $(\mathrm{AOR}=1.62 ; 95 \%$ CI: 2.6, 10.20) were predictors for TB. Conclusion. Nine prisoners were TB positive. One case showed rifampicin resistance and three had TB/HIV coinfection. Marriage, HIV, and sharing of rooms were predictors for TB. Prevention/control and monitoring are mandatory in such settings.
\end{abstract}

\section{Background}

Tuberculosis is caused by Mycobacterium tuberculosis (Mtb) and occasionally by an Mtb complex [1]. It is very common and is spread from person to person via air by droplet nuclei produced when a person with TB coughs, sneezes, talks, or sings [2]. One-third of the world's population are infected with Mtb; Eastern Europe, Southeast Asia, and sub-Saharan Africa exhibit the highest incidence [3]. In developing countries, $7 \%$ of all deaths are attributed to $\mathrm{TB}$ [4].

Tuberculosis has been recognized as a major public health problem in Ethiopia since the 1950s, and efforts to control it have continued since then [5], although it is an ancient disease that has affected mankind for more than 4,000 years [4]. Ethiopia ranks 7th in the world for TB burden and 3rd in Africa in 2008, with an estimated incidence of 378 new cases per 100,000 persons, 163 new smear positives per 100,000 persons, and a prevalence of 579 per 100,000 population [1]
It was the 3rd leading cause of patients' death (10.1\%) in 2001 [6].

Tuberculosis in prisons usually exceeds 3,000 per 100,000 persons. Incidence and mortality rates owing to $\mathrm{TB}$ in prisons are higher [7]. Tuberculosis and HIV are two of the greatest health threats in African prisons [8]. The fast growing epidemic of TB in the prisoners in sub-Saharan Africa constitutes a threat to both inmates and the community [9]. There is an increasing recognition that the high risk of TB disease in prison settings poses a problem for prisoners and communities. Transmission in prisons is also particularly dangerous as it often involves resistant strains [10].

Studies carried out in Pakistan showed $48 \%$ latent TB cases among 425 prisoners [11] and 2.2\% TB cases among 365 randomly selected imprisoned men [10]. Another study carried out in Khuzestan, Iran, revealed 7.9\% TB cases among 4562 prison inmates [12] and 4.5\% TB cases among 59 prisoners in Tajikistan [13]. Of 15,495 TB suspected inmates screened in 13 Ethiopian prisons, 765 (4.9\%) had TB [14]. 
A study carried out in Eastern Ethiopian prisons revealed 8.9\% TB cases among 371 prisoners [15], 19.4\% in Gamo Gofa Zone [16], 1.83\% in Hadiya zone [17], and 21.9\% among 196 prisoners at the Bedele Woreda prison [18]. Another study conducted in prisons found in North Ethiopia also revealed that TB accounted for $8.0 \%$ in eight prisons [19], 10.4\% from 250 prisoners [20], and 8.9\% smear positive PTB [21].

A study done in Ghana revealed that HIV seroprevalence was $4.9 \%$ among prisoners [22]. A report in Abuja, Nigeria, prison depicted that HIV positivity was 6\% among 200 prisoners [23]. A study conducted in a prison in Uganda showed that the prevalence of HIV was $4.1 \%$ among 248 prisoners [24]. Studies conducted in North Gondar prisons revealed that HIV positivity rates were $7.6 \%$ among 250 prisoners [20] and $12.3 \%$ among 114 TB patients [25].

Multidrug-resistant- (MDR-) TB cases in prisons are often higher than has been reported in the general population [7]. A report in Russia showed that the prevalence of isoniazid, rifampicin, streptomycin, ethambutol, and pyrazinamide resistance in new TB cases in prisoners was $38.0 \%, 25.2 \%, 34.6 \%, 14.7 \%$, and $7.2 \%$, respectively [26]. Another study done in Russian prison inmates indicated that rifampicin resistance was $58.2 \%$ among 140 prisoners [27]. MDR-TB also remains a critical health problem in Ethiopia and its prevalence was $1.6 \%$ and $11.8 \%$ among new and retreatment cases, respectively [28]. Another report in Amhara National Regional State, Ethiopia, also indicated that rifampicin resistance rate was $2.8 \%$ among 606 suspects of MDR-TB (Nigus et al., 2015).

People in congregated settings like prisons and refugee camps are at high risk for acquisition of TB due to overcrowding, close living conditions, insufficient ventilation, low socioeconomic status, and poor nutrition and health of prison inmates $[10,29,30]$. A Pakistani report revealed that prisoners' educational level, smoking status, and duration of current incarceration in prison were found to be $(p<$ 0.05) predictors of Mtb infection [11]. A study indicated that most prison settings encounter a variety of challenges which hinder TB control: insufficient laboratory capacity and diagnostic tools, interrupted supply of medicines, weak integration between civilian and prison TB services, inadequate infection control measures, and low policy priority for prison healthcare [11].

Various studies in Ethiopian prison settings also explained that educational status, HIV, diabetes, malnutrition, alcoholism, smoking cigarettes, poverty, and being in prison, history of TB treatment, TB contact history, cough $>2$ weeks before diagnosis, night sweating, decreased body mass index, poor ventilation of the room, and length of imprisonment were the commonest identified risk factors for TB $[16,18-20,31]$.

\section{Materials and Methods}

2.1. Study Area. This study was carried out in East Gojjam Zone, in three prison sites: Motta, Bichena, and Debre Markos. The prisons serve as a central destination for inmates coming from many surrounding smaller prisons or police stations. Selection of these prisons for the study was based on their role as central prisons, easy for sample transportation and cooperation from the relevant administrative body. Based on the recent year's national census, East Gojjam Zone has a total population of $1,670,685$, of whom 827,145 are men. The total prisoners in this zone were 2700, of whom 2628 were men. This zone has one referral hospital, three currently working primary hospitals, 101 health centers, 406 health posts, 1 higher clinic (private), 21 medium private clinics, and 3 specialty clinics.

2.2. Study Design and Period. An institution based crosssectional study was conducted from February to May 2016.

\subsection{Population}

2.3.1. Source Population. The source population included all prisoners in East Gojjam Zone at the time of the study.

2.3.2. Study Population. The study population included all prisoners who had cough for more than two weeks during the study period.

\subsection{Inclusion and Exclusion Criteria}

2.4.1. Inclusion Criteria. Study participants who had cough for more than two weeks were included.

2.4.2. Exclusion Criteria. Those who failed to give sputum specimens and consent were excluded.

\subsection{Variables}

2.5.1. Dependent Variables. Prevalence of tuberculosis was the dependent variable.

2.5.2. Independent Variables. Independent variables were age, sex, marital status, duration of cough, place of residence before incarceration, occupation before imprisonment, educational status, number of prisoners per cell, length of stay in the prison, previous anti-TB treatment, diabetes mellitus, HIV status, cigarette smoking, and sharing of cells with TB patients.

\subsection{Sample Size Determination and Sampling Technique}

2.6.1. Sample Size. Sample size was determined using a single population proportion formula by assuming a prevalence of $19.4 \%[16]$.

$$
\begin{aligned}
& n=\frac{Z_{\alpha / 2}{ }^{2} P(1-P)}{d^{2}}, \\
& n=\frac{(1.96)^{2} 0.194(1-0.194)}{0.05^{2}}, \\
& n=241,
\end{aligned}
$$

where $n$ is the sample size, $Z$ is the $z$-score for 95\% CI (1.96), $P$ is the prevalence (19.4\%), and $d$ is the margin of error (5\%). 
Adding a $10 \%$ nonresponse rate gave us 265 . The number of study participants from each study area was calculated as follows: number of prisoners in Debre Markos $(n 1)=n f / N \times$ $n 1=265 / 2700 \times 1300=128$; number of prisoners in Bichena $(n 2)=n f / N \times n 2=265 / 2700 \times 880=86$; and number of prisoners in Motta $(n 3)=n f / N \times n 3=265 / 2700 \times 520=51$, where $n f$ is the final sample size, $n i$ is the size of that prison, and $N$ represents total prisoners.

2.6.2. Sampling Technique. There were 2700 prisoners in the specified prison sites during the study period. Health committee members present in each cell were given assignments of recruiting prisoners for the study. They were oriented to recruit inmates who had cough $>2$ weeks, and health professionals interviewed them in prison clinics. Each study participant was selected by a convenient sampling technique.

2.7. Data Collection and Laboratory Investigation. Semistructured and pretested questionnaires were used to collect sociodemographic characteristics and associated factors. Questionnaires were prepared in English and then translated to Amharic and then back to English. Prior to the beginning of data collection, all data collectors were trained on an overview of the assessment and the objectives of the study.

About $1-4 \mathrm{ml}$ of a purulent (mucoid) sputum specimen was collected from prisoners using a sterile falcon tube according to the recommended guideline. Specimens were stored at a maximum temperature of $35^{\circ} \mathrm{C}$ for less than three days and in a $4^{\circ} \mathrm{C}$ refrigerator for 4-10 days until transported to GeneXpert MTB/RIF diagnosis site. The stored sputum sample of each inmate was put in one triple pack container and transported in an icebox within five days of the sample collection to the GeneXpert MTB/RIF laboratory site and analyzed as soon as possible by using the recommended GeneXpert MTB/RIF test protocol [28, 32, 33]. HIV rapid testing was done as per the national HIV testing algorithm guideline [34].

2.8. Quality Control. Pretest was done on individuals who have similar characteristics to this study participant at Bahir Dar Prison to standardize the questionnaire. Completeness of data was cross-checked to ensure whether the right data were entered correctly. Laboratory procedures were performed by following SOPs for GeneXpert MTB/RIF assay. Sample processing control (SPC), probe check control, and internal quality control (IQC) have been always done by the machine itself. In addition, HIV test quality was checked by using previously known HIV positive and negative samples. All materials, equipment, and procedures were adequately maintained and calibrated.

2.9. Data Processing and Analysis. Collected data were computerized using Excel, cleaned, and entered to be analyzed using SPSS version 20.0. Logistic regression was used to explain the effect of independent variables on the outcome variable. $p$ values $\leq 0.05$ were considered statistically significant.

\subsection{Definitions of Terms}

2.10.1. Pulmonary Tuberculosis. Pulmonary tuberculosis is a disease caused by $M$. tuberculosis that mainly affects the lungs.

2.10.2. Rifampicin Resistance. Rifampicin resistance is a surrogate marker of MDR-TB (rifampicin monoresistance tuberculosis).

2.10.3. Associated Risk Factors. These include any attribute, characteristic, or exposure of an individual that increases the likelihood of developing TB.

2.10.4. MDR-TB. This is a form of TB infection caused by bacteria that are resistant to treatment with at least two of the most powerful first-line anti-TB medications (drugs): isoniazid and rifampin.

2.11. Ethical Considerations. The study was started after ethical clearance was obtained from the Ethical and Research Committee of the School of Biomedical and Laboratory Sciences. Written consent was obtained from the study participants. Each confirmed TB case was linked to the health institutions for anti-TB treatment. Pre- and post-HIV test counseling was provided by nurses after written consent and HIV positives were linked to ART clinic. Confidentiality of study participants' data was kept by using code number and locking it in a cupboard and on a computer locked with a password.

\section{Results}

3.1. Sociodemographic Characteristics of the Study Participants. A total of 265 prisoners were recruited in this study, of whom 263 were males. Mean age of the prisoners was 36.5 years with the range of 15 to 72 years, having a normal distribution. Majority (83\%) of the prisoners stayed in the prison for one year; 215 (81.5\%) were imprisoned from rural areas; 261 (98.5\%) were living in prison cells whose windows have been closed. Nearly half of the prisoners (49.1\%) were attending primary school; 20 (83\%) were married; 208 (78.5\%) were farmers, and 258 (97.4\%) were living under the range of 1-89 individuals per cell (Table 1).

3.2. Prevalence of Tuberculosis among Prisoners. Among 265 prisoners, 9 (3.4\%) were positive for Mtb by GeneXpert $\mathrm{MTB} / \mathrm{RIF}$, and all were males. Of these, 7 (77.8\%) were detected to be rural dwellers. Majority (55.6\%) of the TB cases were married. All TB cases were from nonventilated cells where windows were closed all the time and all cases had TB symptoms after admission to the prison (Table 2).

Seven $(2.6 \%)$ prisoners were HIV positive and all were males. Of these, three cases had TB coinfections. Of all HIV cases, 4 (57.1\%) were $>30$ years of age. Four (57.1\%), 6 (85.7\%), and $4(57.1 \%)$ HIV cases were illiterate, farmers, and urban dwellers, respectively (Table 2). About $0.4 \%$ of the prisoners had rifampicin resistant Mtb. 
TABLE 1: Sociodemographic characteristics of prison inmates in East Gojjam Zone $(n=265), 2016$.

\begin{tabular}{|c|c|c|c|}
\hline Variable & Response & Frequency & $\begin{array}{l}\text { Percent } \\
(\%)\end{array}$ \\
\hline \multirow{2}{*}{ Age in years } & $15-30$ & 98 & 37.0 \\
\hline & $>30$ & 167 & 63.0 \\
\hline \multirow{2}{*}{ Sex } & Male & 263 & 99.2 \\
\hline & Female & 2 & 0.8 \\
\hline \multirow{3}{*}{ Marital status } & Single & 39 & 14.7 \\
\hline & Married & 220 & 83.0 \\
\hline & Divorced & 6 & 2.3 \\
\hline \multirow{4}{*}{ Educational status } & Uneducated & 102 & 38.5 \\
\hline & Primary school & 130 & 49.1 \\
\hline & Secondary school & 31 & 11.7 \\
\hline & Tertiary school & 2 & 0.8 \\
\hline \multirow{2}{*}{ Residence } & Rural & 215 & 81.1 \\
\hline & Urban & 50 & 18.9 \\
\hline \multirow{4}{*}{ Occupation } & Farmer & 208 & 38.5 \\
\hline & Government employed & 11 & 49.1 \\
\hline & Self-employed & 27 & 11.7 \\
\hline & Student & 19 & 0.8 \\
\hline \multirow{4}{*}{$\begin{array}{l}\text { Length of stay in } \\
\text { prison }\end{array}$} & $<2$ months & 12 & 4.5 \\
\hline & 2-6 months & 22 & 8.3 \\
\hline & $7-12$ months & 11 & 4.2 \\
\hline & $>12$ months & 220 & 83.0 \\
\hline \multirow{2}{*}{$\begin{array}{l}\text { Number of } \\
\text { prisoners per cell }\end{array}$} & $1-89$ & 258 & 97.4 \\
\hline & $>89$ & 7 & 2.6 \\
\hline
\end{tabular}

3.3. Factors Associated with Tuberculosis among Prisoners. Using binary and multivariable logistic regression analysis, we found that marital status $(\mathrm{COR}=4.9,95 \% \mathrm{CI}=$ 1.258-19.194; $\mathrm{AOR}=1.5,95 \% \mathrm{CI}=1.7-13.03)$, HIV status $(\mathrm{COR}=31.5,95 \% \mathrm{CI}=5.74-172.74 ; \mathrm{AOR}=0.14,95 \% \mathrm{CI}=$ 0.001-0.17), and sharing of cells with TB patients (COR $=$ $4.83,95 \% \mathrm{CI}=1.14-20.56 ; \mathrm{AOR}=1.62,95 \% \mathrm{CI}=2.6-10.20)$ in the prison were significantly associated with TB positivity (Table 2). This meant that the odds of having TB infections among the married prisoners were $1.5[\mathrm{AOR}=1.5,95 \% \mathrm{CI}$ : 1.7-13.03] times higher than in those who were not married. Similarly, the odds of having TB infections among those study participants who shared living cells/rooms with TB patients were $1.6[\mathrm{AOR}=1.62,95 \% \mathrm{CI}: 2.6-10.20]$ times more than in those who did not have such an experience. Lastly, being HIV negative among prisoners was $86 \%$ more likely to be protected from $\mathrm{TB}$ infections as compared to those prisoners who had HIV infection $[A O R=\mathbf{0 . 1 4}, 95 \%$ CI: 0.001-0.17].

\section{Discussion}

This study was aimed at determining the prevalence and associated factors of TB infection in the prison settings in East Gojjam Zone, Northwest Ethiopia. Prevalence of TB in prisoners is usually higher than the national average [35]. However, our study indicated that the prevalence of $\mathrm{TB}$ among prisoners in East Gojjam Zone has been found to be lower than in the previous studies conducted in the Amhara National Regional State (8.0\%) [19], in North Gondar Zone prisons (10.4\% [20] and 8.9\% [21]), and in Eastern Ethiopian
Prison (8.9\%) [15]. The possible reasons for the difference might be associated with the variation of the diagnostic methods used, such as sputum microscopy, culture, and GeneXpert by the previous study and GeneXpert in our case. This low prevalence may also mean that there might be a comparatively good TB infection control in the prison management system of East Gojjam prisons. The higher rates in other cases may also mean that there were no good TB control systems in such a setting. On the other hand, our prevalence rate is higher than in the studies conducted on prisoners in Ghana (0.9\%) [36] and Uganda (2.0\%) [24]. The probable explanation for this difference might be due to the variation of study settings, study population, diagnostic methods used, and better TB control systems in these countries than in Ethiopia.

The prevalence rate of the present study was nearly comparable to the results of the study done on prisons in Ethiopia (4.9\%) [16], Tajikistan (4.5\%) [13], and South Africa (3.5\%) [37]. The possible explanation of the similarity might be that whatever different methodologies they may have used, they may have implemented good comparable preventive and diagnostic strategies in their prison settings.

Our study showed low TB prevalence when compared with the study from Gamo Gofa zone (19.4\%) [16]. The possible explanation for this difference might be due to the diagnostic methods employed, which included sputum microscopy and culture in Gamo Gofa and GeneXpert in our case. The potential reason for this difference may mean also that there are no good TB control systems in the prisons of Gamo Gofa. Tuberculosis prevalence among prisoners in our study was lower than the prevalence in Nigeria (54.2\%) [38], Pakistan (48\%) [11], and Southern Iran (7.9\%) [12]. High rates of TB in Nigeria and Pakistan were not comparable with that of ours: it seems that there are no systems of initial screening for TB and prisoners' health services in such prisons.

Prevalence of HIV infection in our study was lower than in the reports from prisons in Gondar (7.6\%) [20], Ghana (4.9\%) [22], Nigeria (6\%) [23], Uganda (4.1\%) [24], and North Gondar (12.3\%) [25]. The difference is possibly due to the discrepancies in testing algorithms.

Rifampicin resistant prevalence in the current study was lower than the result of the previous study conducted in the Amhara National Regional State (2.8\%) [39]. The finding of our study was much lower than the reports in Russia (25.2\% [26] and 58.2\% [27]). The possible explanation might be that in Russia they may have had very high rates of MDR-TB. Dramowski et al. [40] reported that rifampicin resistant TB is increasingly encountered particularly among HIV infected children in Cape Town province. Saunders et al. [41] reported in Bujumbura the appearance of MDR-TB and rifampicin resistance in new cases. Toraore et al. [42] reported rifampicin resistance in $\mathrm{Mtb}$ isolates from diverse countries by a commercial line probe assay as an initial indicator of MDR-TB. Hence, rifampicin resistance is still infrequent in our region as a proxy of MDR-TB.

Various factors make prisoners in the prison settings more susceptible to TB infection. Our results revealed that HIV positivity, sharing of cells with TB patients, and marital 
TABLE 2: Prevalence of TB among prisoners $(n=265)$ using GeneXpert MTB/RIF assay, with multivariable analysis showing its associated predictors in East Gojjam Zone, 2016.

\begin{tabular}{|c|c|c|c|c|c|c|}
\hline \multirow{2}{*}{ Variable } & \multirow[b]{2}{*}{ Response } & \multicolumn{2}{|c|}{ TB status } & \multirow[b]{2}{*}{ COR $[95 \% \mathrm{CI}]$} & \multirow[b]{2}{*}{ AOR $[95 \% \mathrm{CI}]$} & \multirow[b]{2}{*}{$p$ value } \\
\hline & & $\begin{array}{l}\text { TB positive } \\
(n=9)\end{array}$ & $\begin{array}{c}\text { TB negative } \\
(n=256)\end{array}$ & & & \\
\hline \multirow{2}{*}{ Age in years } & $\leq 30$ & $5(1.88 \%)$ & $98(36.9 \%)$ & $2.13[0.56-8.12]$ & $0.53[0.10-2.83]$ & 0.460 \\
\hline & $>30$ & $4(1.50 \%)$ & $167(63 \%)$ & 1 & 1 & \\
\hline \multirow{2}{*}{ Marital status } & Single & $4(1.50 \%)$ & $35(13.5 \%)$ & 1 & 1 & 1 \\
\hline & Married & $5(1.88 \%)$ & $221(83.4 \%)$ & $4.9(1.258,19.194)$ & $1.5[1.7-13.03]$ & $0.01^{*}$ \\
\hline \multirow{3}{*}{ Educational status } & Illiterate & $2(0.8 \%)$ & $100(37.7 \%)$ & & $7.63[0.55-105.9]$ & 0.139 \\
\hline & Primary, secondary, & $4(1.50 \%)$ & $126(47.5 \%)$ & & $3.54[0.48-25.73]$ & 0.212 \\
\hline & and above & $3(1.23 \%)$ & $30(11.3 \%)$ & & 1 & \\
\hline \multirow{2}{*}{$\begin{array}{l}\text { Residence before } \\
\text { incarceration }\end{array}$} & Rural & $7(2.64 \%)$ & $208(78.5 \%)$ & $0.81[0.16-4.01]$ & $0.46[0.47-4.6]$ & 0.511 \\
\hline & Urban & $2(0.75 \%)$ & $48(18.1 \%)$ & 1 & 1 & \\
\hline \multirow{2}{*}{$\begin{array}{l}\text { Length of stay in prison in } \\
\text { months }\end{array}$} & $\leq 12$ & $1(0.37 \%)$ & $44(16.6 \%)$ & $0.60[0.073-5.0]$ & $0.9[0.074-10.9]$ & 0.933 \\
\hline & $>12$ & $8(3.01 \%)$ & $212(80 \%)$ & 1 & 1 & \\
\hline \multirow{2}{*}{$\begin{array}{l}\text { Number of prisoners per } \\
\text { cell }\end{array}$} & $1-89$ & $9(3.39 \%)$ & $249(93.9 \%)$ & - & - & 0.615 \\
\hline & $>89$ & $0(0 \%)$ & $7(26.4 \%)$ & & & \\
\hline \multirow{2}{*}{$\begin{array}{l}\text { Ventilation status of the } \\
\text { cells }\end{array}$} & $\begin{array}{l}\text { Window closed at all } \\
\text { times }\end{array}$ & $9(3.39 \%)$ & $252(95 \%)$ & - & - & 0.706 \\
\hline & $\begin{array}{l}\text { Window opened } \\
\text { sometimes }\end{array}$ & $0(0 \%)$ & $4(1.5 \%)$ & & & \\
\hline \multirow{2}{*}{$\begin{array}{l}\text { Sharing cells with TB } \\
\text { patients }\end{array}$} & Yes & $3(1.23 \%)$ & $24(9.05 \%)$ & $4.83[1.14-20.56]$ & $1.62[2.6-10.20]$ & $0.02^{*}$ \\
\hline & No & $6(2.26 \%)$ & $232(87.5 \%)$ & 1 & 1 & 1 \\
\hline \multirow{2}{*}{ Duration of cough in weeks } & $2-4$ & $1(0.37 \%)$ & $102(38.4 \%)$ & $0.19[0.02-1.53]$ & $8.31[0.67-102.6]$ & 0.099 \\
\hline & $>4$ & $8(3.01 \%)$ & $154(58.1 \%)$ & 1 & 1 & \\
\hline \multirow{2}{*}{$\begin{array}{l}\text { Time of occurrence of } \\
\text { cough }\end{array}$} & Before imprisonment & $0(0 \%)$ & $14(5.2 \%)$ & - & - & 0.741 \\
\hline & After imprisonment & $9(3.39 \%)$ & $242(93.4 \%)$ & & & \\
\hline \multirow{2}{*}{$\begin{array}{l}\text { TB symptoms before } \\
\text { admission to the prison }\end{array}$} & Yes & $0(0 \%)$ & $19(7.1 \%)$ & - & - & 0.396 \\
\hline & No & $9(3.39 \%)$ & $237(89.4 \%)$ & & & \\
\hline \multirow{2}{*}{ Cigarette smoking } & Yes & $0(0 \%)$ & $4(1.5 \%)$ & - & - & 0.706 \\
\hline & No & $9(3.39 \%)$ & $252(95 \%)$ & & & \\
\hline \multirow{2}{*}{ Nutritional status } & Normal & $9(3.39 \%)$ & $253(95.4 \%)$ & - & - & 0.471 \\
\hline & Abnormal & $0(0 \%)$ & $3(1.23 \%)$ & & & \\
\hline \multirow{2}{*}{ Diabetes mellitus } & Yes & $0(0 \%)$ & $4(1.5 \%)$ & - & - & 0.706 \\
\hline & No & $9(3.39 \%)$ & $252(95 \%)$ & & & \\
\hline \multirow{2}{*}{ HIV status } & Positive & $3(1.23 \%)$ & $4(1.5 \%)$ & $31.5[5.74-172.74]$ & $0.14[0.001-0.17]$ & $0.001^{*}$ \\
\hline & Negative & $6(2.26 \%)$ & $252(95 \%)$ & 1 & 1 & 1 \\
\hline \multirow{2}{*}{ Previously treated TB } & Yes & $0(0 \%)$ & $22(8.3 \%)$ & - & - & 0.358 \\
\hline & No & $9(3.39 \%)$ & $234(88.3 \%)$ & & & \\
\hline
\end{tabular}

$*$ indicates $p$ value $<0.005$.

status have a statistically significant association with prevalence of TB (Table 1).

\section{Conclusion}

Prevalence of TB in East Gojjam Zone prison inmates is 2.4 times less than the prevalence in the general population of Amhara National Region State (8\%). The HIV prevalence $(2.6 \%)$ in prison inmates of East Gojjam Zone is slightly higher as compared to the national HIV prevalence $(1.14 \%)$ reported in 2014. The number of rifampicin resistant $\mathrm{TB}$ cases found in the current study was $1(0.4 \%)$, which is less than that reported in the Amhara National Regional State $(2.8 \%)$. Furthermore, the factors associated with TB positivity in the present study included HIV status, sharing of cells/living rooms with TB patients, and marital status. Results observed in East Gojjam Zone prisons confirm that TB disease exists among prisoners. These findings are serious problems that should no longer be ignored. Prisoners are the most vulnerable individuals, yet the most marginalized population in our society. Thus, the following recommendations are suggested: (1) screening of all new prisoners for 
TB and HIV before they join; (2) implementing appropriate interventions immediately to control the development and transmission of TB disease in this setting and prevent the spread of TB to the general population; (3) periodic TB screening especially with the use of GeneXpert MTB/RIF test which allows for the timely diagnosis as well as treatment initiation, which is critically important among inmates, so as to effectively control the spread of TB disease in prisons; and (4) precautions against the development of MDR-TB since rifampicin resistance is a probable indicator for the development of MDR-TB though the observation in our study seems to be small.

\section{Conflicts of Interest}

The authors declare that they have no conflicts of interest.

\section{Acknowledgments}

The authors would like to acknowledge the University of Gondar, Motta Hospital, East Gojjam Administrative Zone, Motta, Bichena, and Debre Markos prison administration, and people who are working in the Heal TB Project for their valuable contributions to this study. Special thanks also go to the study participants who were voluntarily employed in this study.

\section{References}

[1] Federal Democratic Republic of Ethiopia, "First Ethiopian National Population based Tuberculosis prevalence survey, Addis Ababa, Ethiopia," 2011.

[2] Department of Health, "National Tuberculosis Management Guideline, Republic of South Africa," 2014.

[3] P. R. Murry, K. S. Rosental, and S. George, Medical Microbiology, 4th edition, 2002.

[4] K. Zaman, “Tuberculosis: A Global Health Problem," Journal of Health, Population and Nutrition, vol. 28, no. 2, pp. 111-113, 2010.

[5] Federal Ministry of Health, Guidelines for Programme and Clinical Management of Drug Resistant Tuberculosis, Ethiopia, 1st edition, 2009.

[6] Y. Birhan, D. Hailemariam, and H. Kloos, Epidemiology and Ecology of Health and Disease, Addis Abeba, Ethiopia, 2006.

[7] D. Masoud, G. Malgosia, E. Michael, R. Harnan, and Z. Andrey, "Guidelines for control of Tuberculosis in prisons: Tuberculosis coalition for Technical Assistance and International committee of the Red Cross," 2009.

[8] G. Henostroza, S. M. Topp, S. Hatwiinda et al., "The high burden of tuberculosis (TB) and human immunodeficiency virus (HIV) in a large Zambian prison: a public health alert," PLOS ONE, vol. 8, no. 8, Article ID e67338, pp. 1-7, 2013.

[9] S. E. Reid, S. M. Topp, E. R. Turnbull et al., "Tuberculosis and HIV control in sub-saharan african prisons: "thinking outside the prison cell”," The Journal of Infectious Diseases, vol. 205, no. 2, pp. S265-S273, 2012.

[10] A. M. Kazi, S. A. Shah, C. A. Jenkins, B. E. Shepherd, and S. H. Vermund, "Risk factors and prevalence of tuberculosis, human immunodeficiency virus, syphilis, hepatitis B virus, and hepatitis $\mathrm{C}$ virus among prisoners in Pakistan," International Journal of Infectious Diseases, vol. 14, no. 3, pp. e60-e66, 2010.
[11] H. Hussain, S. Akhtar, and D. Nanan, "Prevalence of and risk factors associated with Mycobacterium tuberculosis infection in prisoners, North West Frontier Province, Pakistan," International Journal of Epidemiology, vol. 32, no. 5, pp. 794-799, 2003.

[12] S. M. Alavi, P. Bakhtiarinia, M. Eghtesad, A. Albaji, and S. Salmanzadeh, "A Comparative Study on the prevalence and risk factors of tuberculosis among the prisoners in Khuzestan, south-west Iran," Jundishapur Journal of Microbiology, vol. 7, no. 12, Article ID e18872, 2014.

[13] D. E. Winetsky, O. Almukhamedov, D. Pulatov et al., "Prevalence, risk factors and social context of active pulmonary tuberculosis among prison inmates in Tajikistan," PLOS ONE, vol. 9, no. 1, Article ID e86046, 2014.

[14] S. Ali, A. Haileamlak, A. Wieser et al., "Prevalence of Pulmonary Tuberculosis among Prison Inmates in Ethiopia, a CrossSectional Study," PLoS ONE, vol. 10, no. 12, Article ID e0144040, 2015.

[15] D. S. Abebe, G. Bjune, G. Ameni, D. Biffa, and F. Abebe, "Prevalence of pulmonary tuberculosis and associated risk factors in Eastern Ethiopian prisons," The International Journal of Tuberculosis and Lung Disease, vol. 15, no. 5, pp. 668-673, 2011.

[16] Z. Zerdo, M. Girmay, W. Adane, and A. Gobena, "Prevalence of Pulmonary Tuberculosis and Associated Risk Factors in Prisons of Gamo Goffa Zone, South Ethiopia: A Cross-Sectional Study," American Journal of Health Research, vol. 2, no. 5, pp. 291-297, 2014.

[17] T. G. Fuge and S. Y. Ayanto, "Prevalence of smear positive pulmonary tuberculosis and associated risk factors among prisoners in Hadiya Zone prison, Southern Ethiopia Infectious Diseases," BMC Research Notes, vol. 9, no. 1, article no. 201, 2016.

[18] B. B. Winsa and A. E. Mohammed, "Investigation on Pulmonary Tuberculosis Among Bedele Woreda Prisoners, Southwest Ethiopia," International Journal of Biomedical Science and Engineering, vol. 3, no. 6, pp. 69-73, 2015.

[19] F. Biadglegne, A. C. Rodloff, and U. Sack, "A first insight into high prevalence of undiagnosed smear-negative pulmonary tuberculosis in Northern Ethiopian Prisons: Implications for greater investment and quality control," PLoS ONE, vol. 9, no. 9, Article ID e106869, 2014.

[20] B. Moges, B. Amare, F. Asfaw et al., "Prevalence of smear positive pulmonary tuberculosis among prisoners in North Gondar Zone Prison, northwest Ethiopia," BMC Infectious Diseases, vol. 12, article no. 352, 2012.

[21] Z. Addis, E. Adem, A. Alemu et al., "Prevalence of smear positive pulmonary tuberculosis in Gondar prisoners, North West Ethiopia," Asian Pacific Journal of Tropical Medicine, vol. 8, no. 2, pp. 127-131, 2015.

[22] A. A. Adjei, H. B. Armah, F. Gbagbo et al., "Correlates of HIV, $\mathrm{HBV}, \mathrm{HCV}$ and syphilis infections among prison inmates and officers in Ghana: A national multicenter study," BMC Infectious Diseases, vol. 8, article no. 33, 2008.

[23] T. Mohammed, U. Auwal, DR. Baba, and IB. Thilza, "HIV infection among Male prison inmates in Abuja-Nigeria," Researcher, vol. 2, no. 3, pp. 28-30, 2010.

[24] J. Owokuhaisa, E. Thokerunga, and J. Bazira, "Prevalence of Pulmonary Tuberculosis among Prison Inmates at Mbarara Central Prison, South Western Uganda," Advances in Research, vol. 2, no. 11, pp. 618-625, 2014.

[25] M. Beyene, A. Bemnet, A. Fanaye, M. Andargachew, T. Belay, and K. Afework, "High prevalence and poor treatment outcome of tuberclosis in North Gondar zone prison, North west 
Ethiopia," International Journal of Medicines and Medicines, vol. 5, no. 9, pp. 425-429, 2013.

[26] M. Ruddy, Y. Balabanova, C. Graham et al., "Rates of drug resistance and risk factor analysis in civilian and prison patients with tuberculosis in Samara Region, Russia," Thorax, vol. 60, no. 2, pp. 130-135, 2005.

[27] F. Drobniewski, Y. Balabanova, M. Ruddy et al., "Rifampin and multidrug-resistant tuberculosis in Russian civilians and prison inmates: dominance of the Beijing strain family," Emerging Infectious Diseases, vol. 8, no. 11, pp. 1320-1326, 2002.

[28] Federal Democratic Republic of Ethiopia, "Implementation of Guideline for Xpert MTB/RIF Assay in Addis Ababa, Ethiopia," 2013.

[29] Federal Democratic Republic of Ethiopia, "AFB Smear Microscopy Manual, Addis Ababa, Ethiopia," 2009.

[30] World Health Organization (WHO), Tuberculosis Fact Sheet: Global and Regional Incidence, Switzerland, 2007.

[31] A. Yohanes, S. Abera, and S. Ali, "Smear positive pulmonary tuberculosis among suspected patients attending metehara sugar factory hospital; eastern Ethiopia," African Health Sciences, vol. 12, no. 3, pp. 325-330, 2012.

[32] A. S. Kalokhe, M. Shafiq, J. C. Lee et al., "Multidrug-resistant tuberculosis drug susceptibility and molecular diagnostic testing," The American Journal of the Medical Sciences, vol. 345, no. 2, pp. 143-148, 2013.

[33] Xpert ${ }^{\circledR}$ MTB/RIF, “Two-hour detection of MTB and resistance to rifampicin. Cepheid In Vitro Diagnostic Medical Device," 2009.

[34] Federal Democratic Repuplic of Ethiopia, Provider-Initiated HIV Testing and Counseling in Ethiopia, Addis Ababa, Ethiopia, 2010.

[35] World Health Organization, Global Public Health Security in the 21st Century, 2007.

[36] M. Kwabla, D. Ameme, and P. Nortey, "Pulmonary Tuberculosis and Its Risk Factors among Inmates of a Ghanaian Prison," International Journal of TROPICAL DISEASE \& Health, vol. 9, no. 3, pp. 1-10, 2015.

[37] L. Telisinghe, K. L. Fielding, J. L. Malden et al., "High tuberculosis prevalence in a South African prison: The need for routine tuberculosis screening," PLoS ONE, vol. 9, no. 1, Article ID e87262, 2014.

[38] N. Lawrence and U. Christian, "Incidence and Spread of Mycobacterium tuberculosis-associated infection among prison inmates in Nigeria," Journal of Health, Population and Nutrition, vol. 28, no. 4, pp. 327-332, 2010.

[39] D. M. Nigus, W. M. Lingerew, B. A. Beyene, A. A. Tamiru, M. T. Lemma, and M. Y. Melaku, "Prevalence of Multi Drug Resistant Tuberculosis among Presumptive Multi Drug Resistant Tuberculosis Cases in Amhara National Regional State, Ethiopia," Mycobacterial Diseases, vol. 04, no. 03, 2014.

[40] A. Dramowski, M. M. Morsheimer, A. M. Jordaan, T. C. Victor, P. R. Donald, and H. S. Schaaf, "Refampicine resistant mycobacterium tuberculosis disease among children in South Africa," The international Journal of TB and Lung Disease, vol. 16, no. 1, pp. 76-81, 2012.

[41] M. Saunders, A. Van Deun, D. Ntakirutimana, J. Masab, and J. Rukundo, "Rifampicin mono-resistant Mycobacterium tuberculosis in Bujumbira," International Journal of Tuberculosis and Lung Disease, vol. 10, pp. 178-183, 2006.

[42] H. Toraore, R. Fisste, I. Bastian, M. Devleeschooker, and F. Portaels, "Detection of refampicin mono resistant in mycobacterium isolates from diverse countries by a commercial line probe assay: an initial medication of MDR," InternatIonal Journal of TB and Lung Disease, vol. 4, pp. 481-484, 2000. 

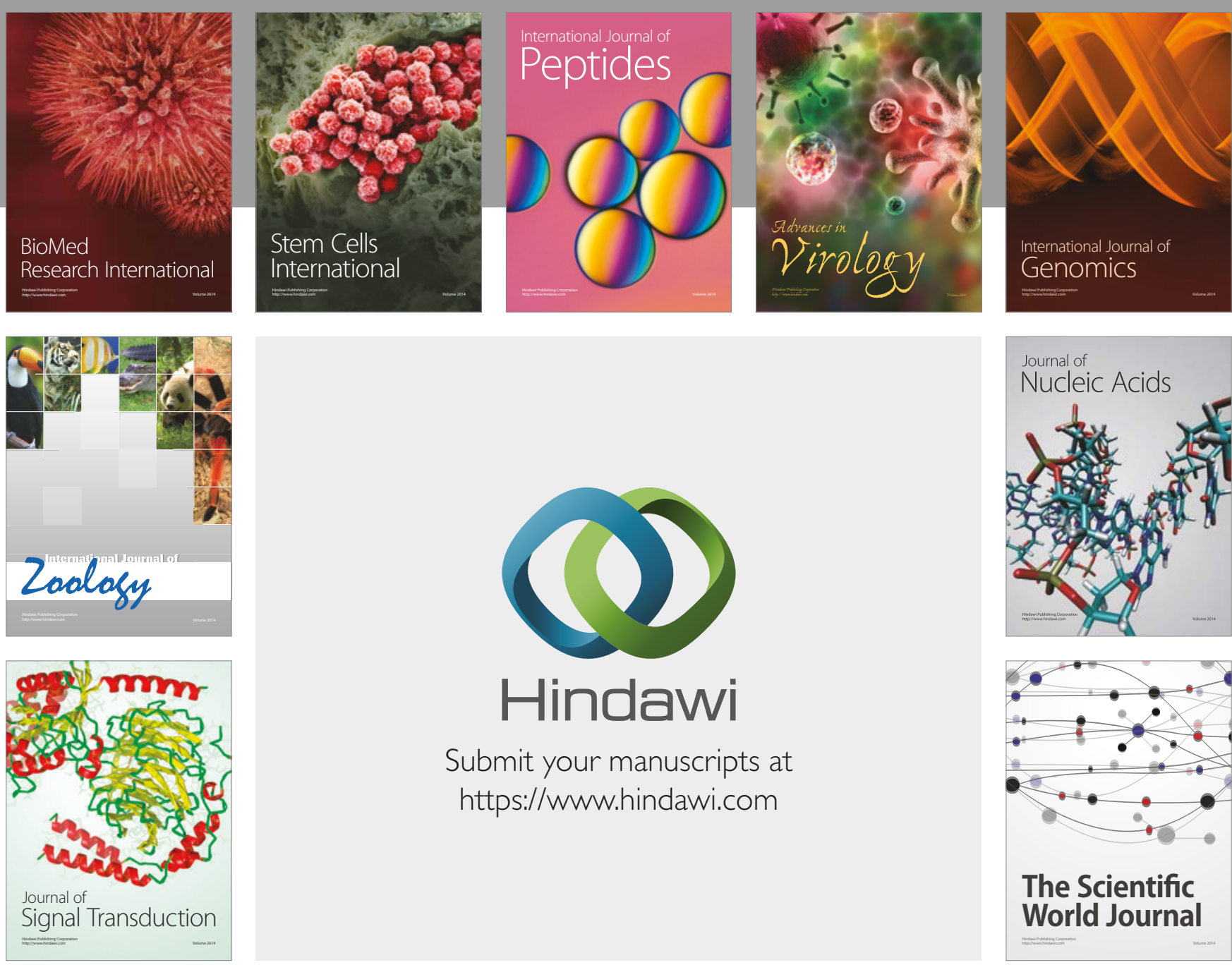

Submit your manuscripts at

https://www.hindawi.com
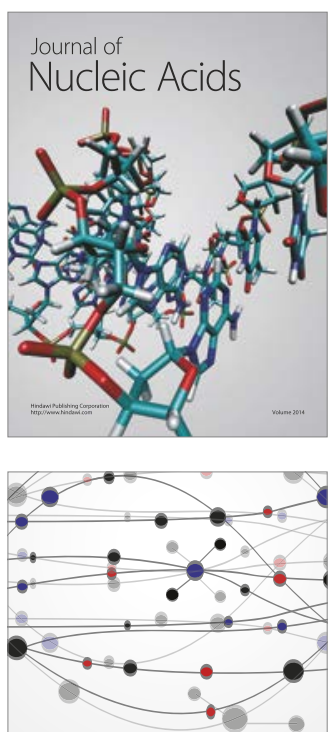

The Scientific World Journal

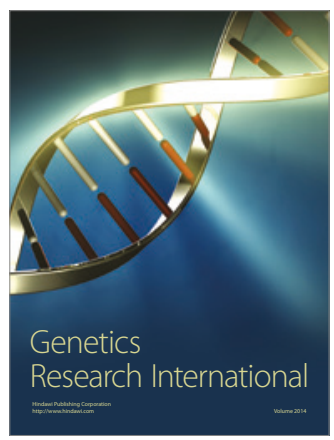

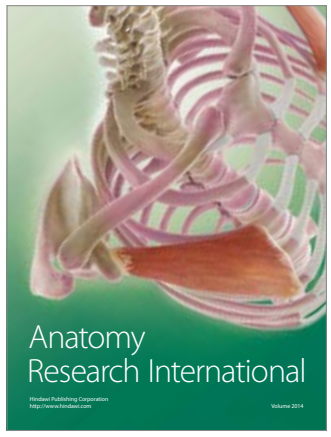

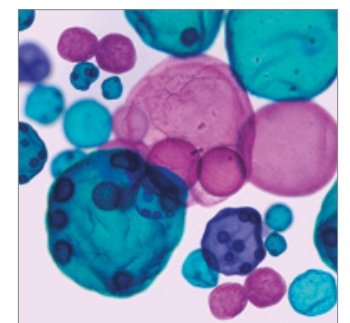

International Journal of Microbiology
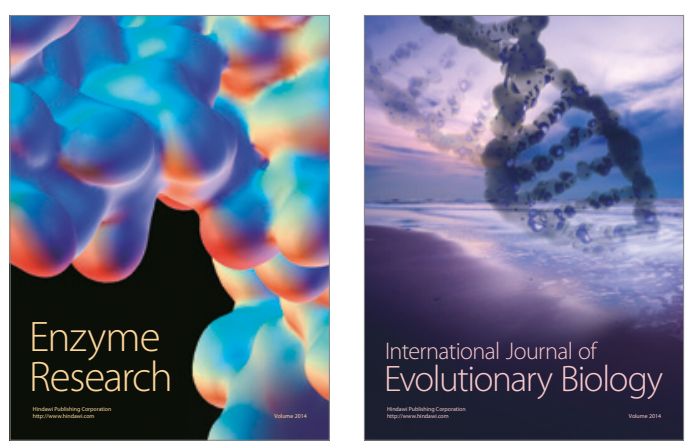
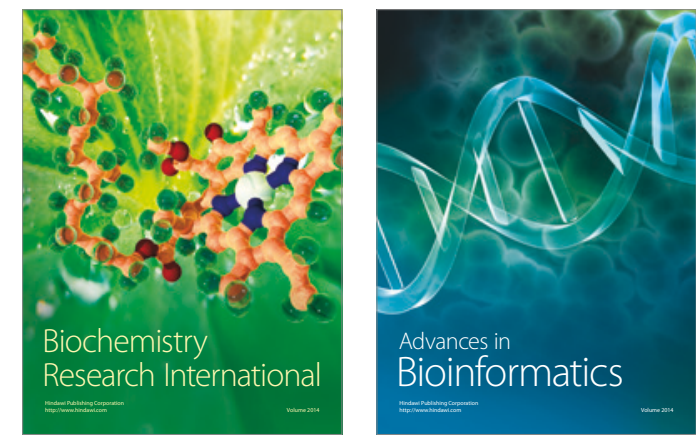

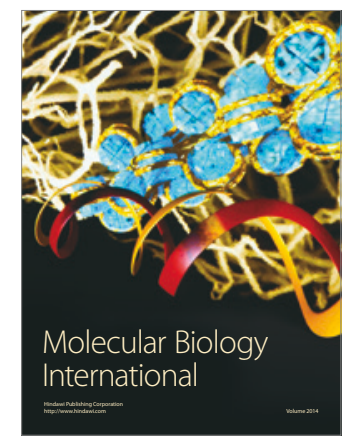

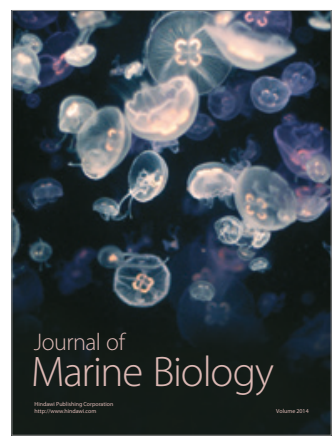

